\title{
The Progression in the Mouse Skin Carcinogenesis Model Correlates With ERK1/2 Signaling
}

\author{
Kostas D. Katsanakis, ${ }^{1}$ Vassilis Gorgoulis, ${ }^{2}$ Athanasios G. Papavassiliou, ${ }^{3}$ and Vassilis K. Zoumpourlis ${ }^{1}$ \\ ${ }^{1}$ Institute of Biological Research and Biotechnology, National Hellenic Research Foundation, Athens, Greece \\ ${ }^{2}$ Department of Histology and Embryology, School of Medicine, University of Athens, Athens, Greece \\ ${ }^{3}$ Department of Biochemistry, School of Medicine, University of Patras, Patras, Greece
}

Accepted August 27, 2002

\begin{abstract}
Background: The ras family of proto-oncogenes encodes for small GTPases that play critical roles in cell-cycle progression and cellular transformation. ERK1/2 MAP kinases are major ras effectors. Tumors in chemically treated mouse skin contain mutations in the Ha-ras protooncogene. Amplification and mutation of Ha-ras has been shown to correlate with malignant progression of these tumors. Cell lines isolated from mouse skin tumors represent the stages of tumor development, such as the PDV:PDVC57 cell line pair and B9 squamous carcinoma and A5 spindle cells. PDVC57 cells were selected from PDV cells, which were transformed with dimethylbenzanthracene (DMBA) in vitro and then transplanted in adult syngeneic mice. The PDV:PDVC57 pair contains ratio of normal:mutant Ha-ras 2:1 and 1:2, respectively. This genetic alteration correlates with more advanced tumorigenic characteristics of PDVC57 compared to PDV. The squamous carcinoma B9 cell clone was isolated from the same primary tumor as A5 spindle cell line. The mutant Ha-ras allele, also present in B9, is amplified and overexpressed in A5 cells. Therefore these cell line pairs represent an in vivo model for studies of $\mathrm{Ha}$-ras and ERK1/2 signaling in mouse tumorigenesis.
\end{abstract}

Materials and Methods: The ERK1/2 status in the above mouse cell lines was examined by using various molecular techniques. For the study of the tumorigenic properties and the role of the ras/MEK/ERK1/2 pathway in the cell lines mentioned, phenotypic characteristics, colony formation assay, anchorage-independent growth, and gelatin zymography were assessed, after or without treatment with the MEK inhibitor, PD98059.

Results: ERK $1 / 2$ phosphorylation was found to be increased in PDVC57 when compared to PDV. This also applies to A5 spindle carcinoma cells when compared to squamous carcinoma and papilloma cells. The above finding was reproduced when transfecting human activated Ha-ras allele into PDV, thus demonstrating that Ha-ras enhances ERK 1/2 signaling. To further test whether ERK 1/2 activation was required for growth we used the MEK-1 inhibitor, PD98059. The latter inhibited cell proliferation and anchorage-independent growth of squamous and spindle cells. In addition, PD98059 treatment partially reverted the spindle morphology of A5 cells.

Conclusions: These data suggest, for the first time, that oncogenicity and the degree of progression in the mouse skin carcinogenesis model correlates with ERK1/2 signaling.

\section{Introduction}

The ras proto-oncogene, which is found mutated in $30 \%$ of human tumors and higher in certain tumor types, is also involved in tumor development in rodents (1). During treatment of mouse skin with chemical carcinogens, Ha-ras is mutated at specific codons activating its transforming potential (2). In the mouse skin multistage carcinogenesis model Haras alterations occur during the papilloma-squamousspindle carcinoma stages (3) (Fig. 1). Interestingly, during the squamous-spindle stage a genotypic difference occurs in the normal:mutant Ha-ras alleles ratio (4) (Fig. 1). The altered ratio of normal:mutant Ha-ras is maintained in the spindle stage of the carcinogenic process and is strongly associated with a

Address correspondence and reprint requests to: Vassilis Zoumpourlis, Institute of Biological Research and Biotechnology, National Hellenic Research Foundation, 48 Vas. Constantinou Ave, Athens 116 35, Greece. Phone: +3010-7273745; fax: +3010-7273677; e-mail: vzub@eie.gr. more tumorigenic and invasive cell behavior (5) (Fig. 1).

Although a great number of studies in ras signaling have been published during the last years, the vast majority of these deal with fibroblasts, which are not directly relevant to the role of mutant Ha-ras in epithelial tumorigenesis. The majority of naturally occurring ras mutations are found in epithelial and not mesenchymal tumor types. In rodent fibroblasts several lines of evidence support that the ras/raf/MAPK pathway is necessary and sufficient to induce transformation (6-8). However, this does not seem to be the case in other contexts because other effector pathways appear to contribute to, or be required for, ras-responses including phosphatidylinositol-3OH-kinase (PI3K) (9), protein kinase $\mathrm{C} \zeta$ (10), MEKKl (11), protein p120 GAP (12), and RalGDS and RGL proteins (13). Therefore, it is apparent that the candidate intracellular targets of rasinduced proliferation are far from clear, even within a given cell type. 


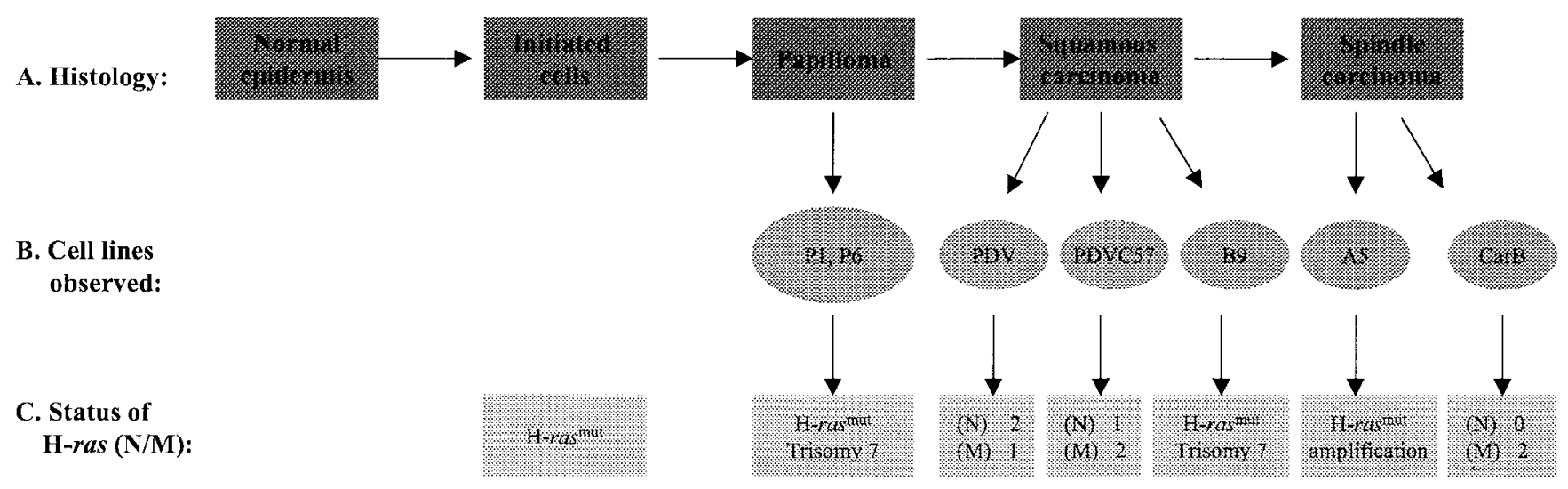

Fig. 1. Representation of the mouse skin carcinogenesis model system. Initiation of carcinogenesis was achieved through treatment of the epidermis with DMBA resulting in a mutation in Ha-ras (35). Progression to later stages was carried out with sequential treatment with 12-O-tetradecanoyl-phorbol-13-acetate (TPA). The latter results in the appearance of papillomas, some of which progress to squamous cell carcinomas. During these phenotypic alterations, quantitative and qualitative changes of the Ha-ras gene are observed $(2,21)$. (A) Histologic lesions after treatment of normal epidermis with DMBA and TPA. (B) Cell lines derived from the various stages of the mouse skin carcinogenesis model. (C) Ha-ras status where $\mathrm{N}=$ normal and $\mathrm{M}=$ mutant.

A series of cell lines representing different stages of mouse skin tumor progression have been developed (Fig. 1). These cell lines are representative for the three distinct stages in mouse carcinogenesis, which include benign papillomas, locally invasive squamous carcinomas, and metastatic spindle carcinomas. The clonally related squamous (B9) and spindle (A5) cells carry identical mutations in both $\mathrm{H}$-ras and $p 53$ genes (14). These cells therefore allow comparison of the specific changes associated with malignant progression. The epidermal cell line (PDV) transformed in vitro by dimethylbenzanthracene (DMBA) treatment (15) and a derivative line (PDV57) obtained by transplantation in a syngeneic host, represent the squamous stage of the mouse skin carcinogenic process. The PDV:PDVC57 differ in the ratio of normal to mutant Ha-ras (4) (Fig. 1), thus representing a useful in vivo tool to examine the role of Ha-ras in the progression of carcinogenesis.

To investigate downstream pathways dependent on the quantitative Ha-ras changes, we studied the activation of the MAP kinase pathway in the PDV:PDVC57 squamous cell lines. Furthermore, in an attempt to reproduce the effects of the altered normal:mutant Ha-ras ratio seen in PDVC57, we transfected the parental PDV cell line with a human transforming allele of Ha-ras (16). The following tasks were set: (1) to examine the activation status of ras/MEK/ERK pathway in cycling cultures of PDVras-derived clones as well as in the PDV, PDVC57, and A5 cell lines, which actually represent the malignant spectrum of the mouse skin carcinogenesis model (Fig. 1); (2) to study the tumorigenic properties (colony formation and anchorageindependent growth) of the PDVras-derived clones and compare them with those of the PDV and A5 cell lines; and (3) to investigate the effect of the
MEK-1 inhibitor, PD98059 (17), on the phenotypic and functional characteristics of the above-mentioned cell lines. We demonstrate for the first time that the degree of progression in the mouse skin carcinogenesis model correlates with ERK1/2 signaling.

\section{Materials and Methods Materials}

Dulbecco's modified Eagle Medium (DMEM), fetal bovine serum (FBS), trypsin, and penicillin/streptomycin were obtained from Gibco (Paisley, Scotland); PD98059 was purchased from Calbiochem (CA, USA); anti-p-ERK mouse monoclonal (SC-7383) and mouse anti-Ha-ras antibody (SC-35) were from Santa Cruz Biotechnology (Santa Cruz, CA, USA); sheep anti-ERK-2 antibody was a gift from Prof. P. Cohen (Dundee, UK); rabbit anti-Fra-l antibody was kindly provided by Prof. M. Yaniv (Institut Pasteur, Paris, France); chemiluminescence reagent was obtained from Pierce (USA).

\section{Generation and Description of Our Experimental System}

Most of the cell lines used have been described previously $(18,19)$. P1 and P6 are papilloma lines isolated from DMBA/TPA-treated Mus spretus X CBA F 1 hybrid mice (20). B9 is a squamous cell carcinoma from a multiple DMBA-treated $M$ spretus $\mathrm{X}$ CBA $F_{1}$ hybrid mouse, and $\mathrm{A} 5$ is a spindle cell carcinoma variant isolated from the same tumor (19). CarB are highly aggressive spindle cell carcinomas isolated from NIH mice after DMBA/TPA treatment (21). PDV cells were derived by in vitro transformation with DMBA of primary keratinocytes from C57BI mice (15). PDVC57 cell line was established from a tumor resulting from injection of PDV cells into C57B 1 mice (5). All these cell lines carry the Ha-ras mutation at codon 61, which is typically induced by DMBA (22). 


\section{Tissue Culture Experiments}

The cell lines P1, P6, B9, PDV, PDVC57, A5, and CarB were passaged in DMEM supplemented with $10 \%$ FBS and penicillin/streptomycin.

For colony staining and morphology, cells were plated in 6-well dishes, allowed to grow for 24-48 hr and then were left untreated or treated with $50 \mu \mathrm{M}$ of PD98059. For colony staining the cells were washed with PBS briefly, fixed in $100 \%$ methanol for $5 \mathrm{~min}$ at room temperature, stained with $0.5 \%$ crystal violet (Sigma, St. Louis, MO, USA) for $10 \mathrm{~min}$ at room temperature; excess dye was removed by water. To estimate cell number of crystal violet-stained cells in 6-well plates, those were dissolved in $1 \mathrm{ml}$ of $30 \%$ acetic acid and absorbance was measured in a Hitachi-Spectrophotomoter (595 $\mathrm{nm})$. The values in the graphs represent the average of three determinations.

The photomicrographs of control and PD98059treated cells were taken with a Zeiss Axiophot inverted microscope at $20 \times$ magnification.

\section{Transfection of Activated Ha-ras}

PDV mouse cells were transfected by the calcium phosphate method with $5 \mu \mathrm{g}$ per $10-\mathrm{cm}$ dish of pHO61 DNA plasmid carrying an activated Ha-ras oncogene (16). Thirty percent confluent cells were incubated with precipitated DNA for $24 \mathrm{hr}$, washed twice with PBS, and then incubated with DMEM supplemented with $10 \%$ FBS for 24 hr. Following this period the transfection plate was divided into 10 dishes and after $24 \mathrm{hr}$ the DMEM was replaced with DMEM containing G418. The colonies were maintained in G418 selection for 2-3 weeks. Colonies were isolated by cylinder trypsinization and transferred to 6-well dishes to expand them for freezing and further experimentation.

\section{Soft Agar Growth}

Agarose (0.6 and 0.3\%) in DMEM containing 10\% FBS was prepared. The mix was cooled to $42^{\circ} \mathrm{C}$. Two milliliters of $0.6 \%$ agarose/DMEM mix was layered onto the wells of each of a 6-well plate and allowed to cool for $10 \mathrm{~min}$. Cells were trypsinized and resuspended in DMEM containing $10 \%$ FBS. Cells $(3 \times$ $10^{3}$ ) were mixed with $0.3 \%$ agarose/DMEM solution and placed immediately on the top of $0.6 \%$ agar. The cells were allowed to grow for 3 weeks. Every 3 days, $300 \mu$ l of DMEM with 10\% FBS was placed on top of the $0.3 \%$ layer (to prevent drying) with PD98059 or vehicle alone.

\section{Preparation of Whole-Cell Lysate}

Cycling cells in DMEM with 10\% FBS were left untreated or treated with $50 \mu \mathrm{M}$ of PD98059 for 1, 6, 24, and $48 \mathrm{hr}$. Following treatment dishes were incubated on ice, washed with ice-cold PBS once and lysis buffer $(20 \mathrm{mM}$ Tris pH 8.0, 0.5\% Triton $\mathrm{X}-100,250 \mathrm{mM} \mathrm{NaCl}, 0.2 \mathrm{mM}$ EDTA, $1 \mathrm{mM}$ phenyl-methyl-sylfonyl-fluoride [PMSF], $1 \mathrm{mM}$ sodium orthovanadate, $10 \mathrm{mM}$ glycerophosphate, $10 \mu \mathrm{g} / \mathrm{ml}$ aprotinin, $10 \mu \mathrm{g} / \mathrm{ml}$ leupeptin, $10 \mu \mathrm{g} / \mathrm{ml}$ trypsin inhibitor) was added. The cells were scraped and transferred into an Eppendorf tube, incubated on ice for $30 \mathrm{~min}$, and cleared by centrifugation at $12,000 \mathrm{rpm}$ for $10 \mathrm{~min}$ at $4{ }^{\circ} \mathrm{C}$ in a Sorvall RMC 14 microfuge. The supernatants were aliquoted and stored at $-70{ }^{\circ} \mathrm{C}$. Protein concentration was evaluated by the Bradford method (BioRad, CA, USA).

\section{Western Immunoblotting}

Thirty-five to fifty micrograms of whole-cell lysates were mixed with Laemmli $2 \times$ sample buffer, boiled, and resolved by $10 \%$ SDS-PAGE polyacrylamide gel electrophoresis using a BioRad mini-gel apparatus. The proteins in the gel were transferred onto nitrocellulose membrane (Sigma) overnight at $30 \mathrm{~mA}$ at room temperature using a BioRad gel transfer apparatus. Nitrocellulose membranes were blocked with $10 \%$ milk/TBST (TBST, $10 \mathrm{mM}$ Tris pH7.6, $100 \mathrm{mM}$ $\mathrm{NaCl}, 0.1 \%$ Tween 20 ) overnight at $4{ }^{\circ} \mathrm{C}$ on a shaking platform. The primary antibodies were incubated in antibody dilution buffer ( $5 \%$ milk/TBST) overnight at $4{ }^{\circ} \mathrm{C}$. After three washes with TBST (10 min each at room temperature), the membranes were incubated with the secondary antibody (1:2000, Santa Cruz) in dilution buffer for $1 \frac{1}{2}$ hr at room temperature. Finally, the membranes were washed three times with TBST (10 min each at room temperature) and submerged into chemiluminescence solution for 90 sec. The membrane was exposed to Fuji Film super RX and the bands were visualized by autoradiography.

\section{Immunoprecipitation of p21 Ha-ras}

Two to four microliters of mouse anti-Ha-ras specific antibody was incubated with $30 \mu \mathrm{l}$ of protein A sepharose (Sigma) for $\mathrm{l} \mathrm{hr}$ at $4{ }^{\circ} \mathrm{C}$ on a rotating wheel. Cells were lysed in lysis buffer as described and $1 \mathrm{mg}$ of whole-cell lysates were used for immunoprecipitation. After binding of the antibody to sepharose, the complex was mixed with the wholecell lysate and incubated overnight at $4{ }^{\circ} \mathrm{C}$ on a rotating wheel. Immunoprecipitates were washed three times with lysis buffer. After the final wash the supernatant was removed and the pellet was adjusted with Laemmli $2 \times$ sample buffer to $30 \mu \mathrm{l}$. The samples were boiled, vortexed thoroughly, and centrifuged, and the supernatants were resolved by $12 \%$ SDS-PAGE. Detection of p21 Ha-ras was performed by Western immunoblotting with the same antibody used for immunopreciptation.

\section{Collection of the Cell-Culture Supernatant and Protein Estimation}

A5 cells were incubated in serum-free DMEM with or without $50 \mu \mathrm{M}$ of PD98059 for $48 \mathrm{hr}$. The supernatant was collected and centrifuged at $1300 \mathrm{rpm}$ for 5 min to remove dead cells. The obtained supernatant 
was pooled and stored in aliquots at $-70{ }^{\circ} \mathrm{C}$. The supernatant was precipitated with $4 \times$ vol of methanol and centrifuged at $11,000 \mathrm{rpm}$ for $1 \mathrm{hr}$. The pellet was dissolved in buffer $\mathrm{E}$ ( $20 \mathrm{mM}$ HEPES pH 8.0, $5 \mathrm{mM}$ EDTA, $10 \mathrm{mM}$ EGTA, $5 \mathrm{mM}$ sodium fluoride, $10 \%$ glycerol, $0.4 \mathrm{M} \mathrm{KCl}, 0.4 \%$ Triton $\mathrm{X}-100,1 \mathrm{mM}$ benzamidine). The protein concentration of the samples was measured against bovine serum albumin (BSA) using the Bradford method (BioRad).

\section{Gelatin Zymography}

Gelatinolytic zymography was performed as described (23). By this method, pro-MMP-9 and the catalytically active MMP-9 were separated according to size by SDS-PAGE. Twenty micrograms of protein was mixed with nonreducing electrophoresis buffer. Electrophoresis was carried out on a $10 \%$ SDS-polyacrylamide gel containing gelatin (Sigma) at a final concentration of $1 \mathrm{mg} / \mathrm{ml}$. After electrophoresis the gels were incubated in a buffer containing $2.5 \%$ Triton $\mathrm{X}-100,150 \mathrm{mM} \mathrm{NaCl}, 10 \mathrm{mM}$ $\mathrm{CaCl}_{2}, 50 \mathrm{mM}$ Tris- $\mathrm{HCl} \mathrm{pH} 7.5$, and $0.05 \%$ sodium azide for $\mathrm{l} \mathrm{hr}$, followed by overnight incubation in the same buffer omitting Triton X-100. The gels were stained with $0.055 \%$ Coomassie blue, destained in $7 \%$ acetic acid and $5 \%$ methanol, and subsequently dried under vacuum.

After completion of the staining process, proMMP-9 (92 kDa) and active MMP-9/Gelatinase B (82 $\mathrm{kDa}$ ) appeared as white bands on a blue background.

\section{Results}

The Various Morphologic Stages of the Mouse Skin Carcinogenesis Model are Associated with a Gradual Increase in ERK1/2 Phosphorylation

It has been previously shown that a reduction in the ratio between normal:mutant $\mathrm{Ha}$-ras is associated with tumorigenicity in squamous cell carcinomas (4). Genetic analysis of squamous cell carcinomas as represented by the PDV and PDVC57 cell lines has shown that they contain normal:mutant Ha-ras genes at ratios 2:1 and 1:2, respectively. Injection of PDV cells into nude mice gives rise to tumors only in about $15 \%$ of injection sites, whereas PDVC57 is more strongly tumorigenic, with tumors diagnosed as squamous carcinomas arising at all injection sites (4). This possibly illustrates that elevated mutant $\mathrm{H}$-ras expression is associated with a more aggressive phenotype. PDVC57 are also 8-fold more invasive and secrete 2 -fold more type IV collagenase than PDV. This evidence suggests that PDVC57 are more tumorigenic, chemotactic, and invasive than PDV (5). Therefore, the degree of progression and invasiveness is in agreement with the altered mutant Ha-ras ratio.

To investigate activation of the MAP kinase pathway, we examined ERK1/2 phosphorylation in the various phenotypic stages of the mouse skin carcinogenetic process (2) (Fig. 1). Whole-cell lysates from P1, B9, A5, and CarB cells were tested in Western immunoblotting assays using a phosphospecific antibody against the dually phosphorylated ERK1/2 (Fig. 2a). A 4.5-fold increase of phosphorylated ERK-1 between P1/B9 epithelial and A5 spindle cells was observed. CarB cells contained the highest levels of phosphorylated ERK1/2. Compared to the P1/B9 cell line they showed a 5.2-fold increase (Fig. 2a). To ensure equal protein loading, the membrane was probed with an antibody specific for total ERK-2 (Fig. 2a, top panel). In addition, phosphorylation of the ERK-2 isoform appeared to be also elevated in the A5 and CarB spindle cells, implying that it is preferentially activated in more advanced tumors (Fig. 2a).

Study of ERK1/2 phosphorylation status in the P6 papilloma cell line and in the PDV:PDVC57 pair revealed that ERK1/2 phosphorylation was more increased in the PDVC57 cell line. The PDVC57 cell line demonstrated a 3.7-fold increase in the levels of phosphorylated ERK-2 when compared to PDV and P6 (Fig. 2b, bottom panel). Furthermore, PDVC57 was also associated with ERK-1 phosphorylation, which was not found in the benign P6 and the less tumorigenic PDV cell lines (Fig. 2b, bottom panel).

Given the fact that the PDVC57 cell line is more aggressive compared to PDV (4), our findings suggest that the cellular behavior in this particular stage (squamous stage) of the mouse skin carcinogenetic process may possibly depend on activation of ERK $1 / 2$.

\section{Introduction of a Transforming Ha-ras Allele Into PDV Cells Alters the Levels of ERK1/2 Phosphorylation}

To examine the effect of transforming Ha-ras on the activation state of ERK1/2, we introduced a human activated Ha-ras allele into PDV (16). After selection with G418, we isolated six colonies termed PDVras $2,3,5,6,7$, and 8 . We analyzed the expression of HaRas protein by Western immunoblotting in PDV, PDVC57, PDVras clone 3, clone 5, and A5 cell lines. We detected increased expression of the total Ha-Ras content in the clones compared to PDV and PDVC57 cell lines (Fig. 2c). To confirm the results of the Western immunoblotting, we also used an immunoprecipitation approach to investigate total Ha-ras protein levels (Fig. 2d). Total p21 Ha-Ras protein was immunoprecipitated from whole-cell lysates of the corresponding cells followed by Western analysis. In the immunoprecipitation experiment we included lysates from A5 cells as a positive control, because they have an amplified Ha-ras gene and the amount of total Ha-Ras protein in the PDV Ras clones 3 and 5 was estimated to be approximately 2 -fold increased in comparison to PDV or PDVC57 (Fig. 2d).

Next, ERK 1/2 phosphorylation was analyzed in the parental PDV:PDVC57 pair and in the PDVras clones by Western immunoblotting (Fig. 2e). PDVras clones 3, 5, and 7 exhibited a relative increase in ERK 1/2 phosphorylation as shown specifically by the levels of phosphorylated ERK-1. In comparison 

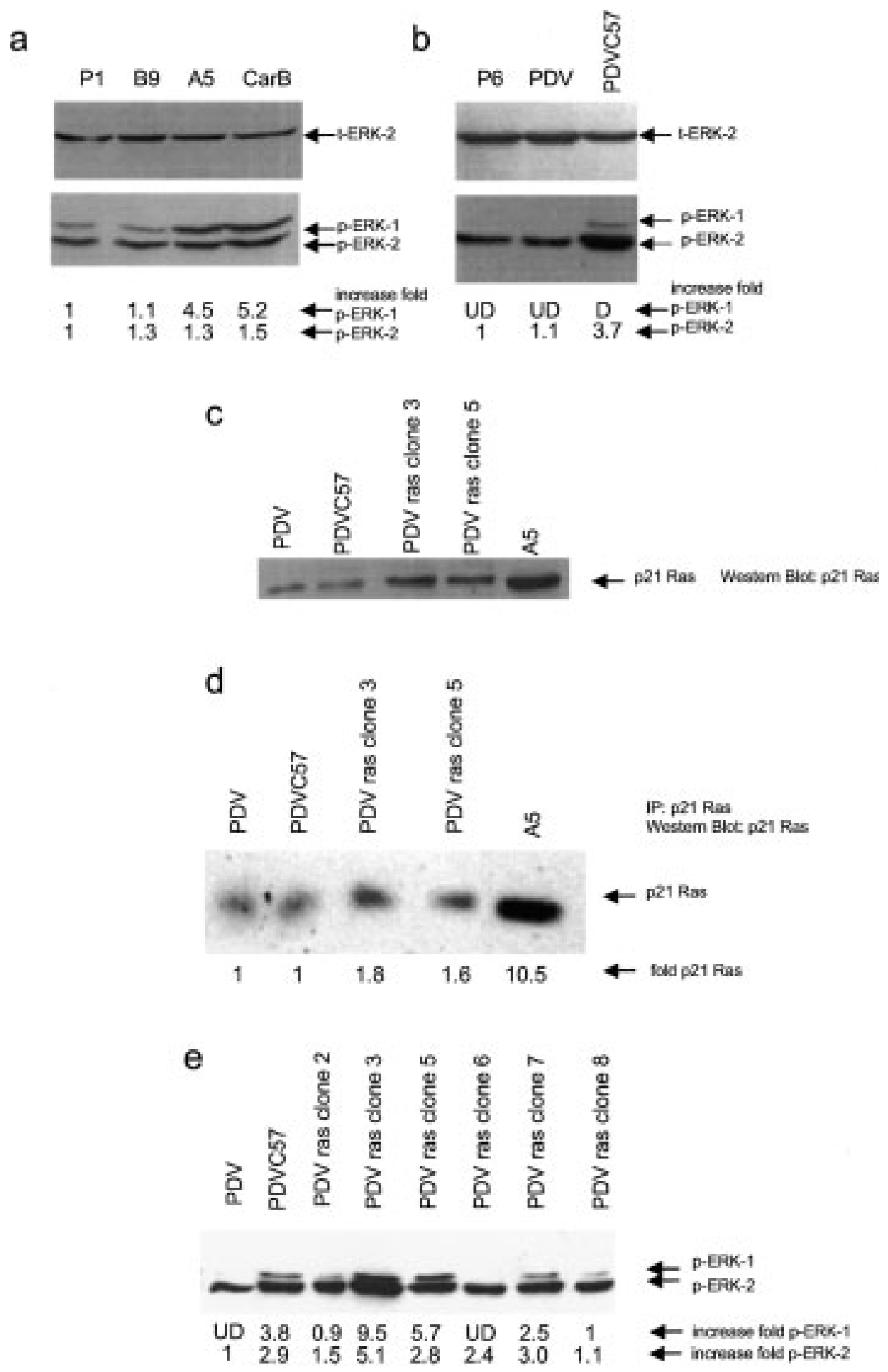

Fig. 2. Analysis of ERK1/2 phosphorylation during various stages of the mouse skin carcinogenesis model. (a) ERK1/2 phosphorylation increases during mouse skin malignant progression. ERK 1/2 phosphorylation was analyzed by Western immunoblotting with an anti-ERK1/2 phosphospecific antibody in P1, B9, A5, and CarB cells (bottom panel). To ensure equal protein loading, the nitrocellulose was probed with ERK-2-specific antibody (top panel). (b) ERK1/2 phosphorylation was analyzed by Western immunoblotting with an anti-ERK1/2 phosphospecific antibody in P6, PDV, and PDVC57 cells (bottom panel). To ensure equal protein loading, the nitrocellulose was probed with ERK-2-specific antibody (a, top panel). (c) Analysis of Ras protein expression by Western immunoblotting with a mouse anti-ras antibody in PDV, PDVC57, PDV ras clone 3, clone 5, and A5 cells. (d) Analysis of Ras protein expression by immunoprecipitation. One milligram of whole-cell lysates was precipitated with a mouse mAb for ras followed by Western immunoblotting with the same antibody. (e) ERK1/2 phosphorylation was analyzed by Western immunoblotting with an anti-ERK1/2 phosphospecific antibody in PDV, PDVC57, and PDVras clones 2, 3, 5, 6, 7, and 8 cells. 
with the parental PDV cell line, the ERK-1 isoform was preferentially activated in five out of the six PDVras isolated clones (Fig. 2e).

These experiments demonstrate that the gradual increase of ERK1/2 activation observed in the PDV:PDVC57 squamous cell line pair is likely to arise from alterations in Ras protein levels/activity.

Colony Formation and Anchorage-Independent Growth of the PDV, PDVC57, PDVras, and A5 Cell Lines are Inhibited by the MEK-1 Inhibitor PD98059

The above observations suggest that quantitative changes in transforming Ha-ras influence the activity of ERK1/2 signaling. Expression of transforming Ha-ras in fibroblasts and some epithelial cells is often associated with cell proliferation (24). To examine whether the in vitro tumorigenic properties of the PDVC57, PDVras clone 3, and A5 cell lines are dependent on activation of the ras/MEK/ERK pathway, we performed colony formation and anchorageindependent growth assays after treatment with the MEK-1 inhibitor, PD98059 for 24, 48, and $72 \mathrm{hr}$ (Figs. 3 and 4). It has been shown that PD98059 inhibits growth factor-induced ERK 1/2 activation, reverts the morphology of Ki-ras transformed cells, and inhibits their anchorage-independent growth (17). Moreover, it suppresses phosphorylation of the Ras exchange factor Sos-1, resulting in downmodulation of Ras activity (25) and in a similar manner with a dominant negative MEK-1 mutant it blocks differentiation of PC12 cells (26).

To visualize growth of colonies, the cells were fixed and stained with crystal violet. As depicted in Figure 3A (left panel with photographs of 6-well plates), colony formation of PDVC57 is markedly altered after treatment with PD98059. Untreated PDVC57 formed colonies efficiently at 48 and $72 \mathrm{hr}$ and inhibition of colony formation by PD98059 was time-dependent and was found to be inhibited at 48 and $72 \mathrm{hr}$. Proliferation of PDVC57 was reduced 3fold at $48 \mathrm{hr}$ and approximately 4 -fold at $72 \mathrm{hr}$ when compared to untreated PDVC57 (Fig. 3A, bottom graph, left panel). Untreated PDVras clone 3 formed small distinct colonies (Fig. 3B, middle panel with photographs of 6-well plates). PD98059 treatment of PDVras clone 3 caused a colony growth reduction at 48 and $72 \mathrm{hr}$. Proliferation was reduced 3.5-fold at $48 \mathrm{hr}$ and approximately 10-fold at $72 \mathrm{hr}$ (Fig. 3B, bottom graph, middle panel). Treatment of A5 cells with PD 98059 for 48 and 72 hr considerably reduced their colony-forming ability (Fig. 3C, right panel with photographs of 6-well plates). Proliferation of A5 cells was reduced 3 -fold at $48 \mathrm{hr}$ and approximately 5.5 -fold at $72 \mathrm{hr}$ (Fig. 3C, bottom graph, right panel). The same effect was observed with PDV cell line (data not shown). The colony-forming potential of cell lines tested was inhibited by the presence of PD98059 by inhibiting the MAPK pathway.

Anchorage-independent growth is one of the hallmarks of transformation and tumorigenicity (27).
Anchorage-independent growth of Ki-ras-transformed epithelial cells has been measured by the growth of cells in soft agar (28). PDV, PDVC57, PDVras clone 3 , and A5 cells were plated in DMEM containing agarose and allowed to grow for 3 weeks. PDV formed very small colonies (Fig. 4a). By contrast, PDVC57 and PDVras clone 3 formed large colonies (Figs. 4c and $4 \mathrm{e})$. As a positive control we also included A5 cells, which being spindle fibroblastic cells, grow efficiently in agar (Fig. 4g). A5 gave rise to colonies of comparable size to those that PDVC57 and PDVras clone 3 cells gave. To examine whether anchorageindependent growth was dependent on ERK1/2 signaling, we tested the effect of PD98059 during soft agar growth. All cell lines were tested in the presence of PD98059 (Figs. 4b, 4d, 4f, and 4h). The results of anchorage-independent growth in soft agar are summarized in Table l. Notably, treatment with DMSO, in which PD98059 was diluted, did not interfere with the efficiency of soft agar cloning (Table 1).

The inhibition of colony formation and anchorageindependent growth of PDVC57, PDVras clone 3, and A5 cells by PD98059 suggests that Ras signaling is involved in proliferation and transformation of these cells.

\section{Treatment with PD98059 Alters Phenotypic Characteristics of the PDVC57, PDVras, and A5 Cell Lines}

In the next step of our study, we examined the effect of PD98059 on the morphology of PDVC57, PDVras clone 3, and A5 cells.

Morphologically, PDVC57 cells form an epithelial monolayer with many cells having a rounded morphology (Figs. 5a and 5c). Treatment of PDVC57 with PD98059 resulted in cell enlargement and disappearance of rounded cells (Figs. $5 \mathrm{~b}$ and $5 \mathrm{~d}$ ). The treated PDVC57 cells did not form a uniform monolayer when compared to the untreated ones for $48 \mathrm{hr}$, possibly due to inhibition of proliferation (Fig. 5, left panel). Untreated PDVras clone 3 cells also show a slight increase in refractability with rounded cells present (Fig. 5e). After treatment, the rounded cells of PDVras clone 3 decreased and the cells acquired a more epithelial morphology (Figs. $5 \mathrm{f}$ and $5 \mathrm{~h}$ ). Finally, A5 controls display a spindle, bipolar morphology (Fig. 5i and 5k); after treatment with PD98059, the spindle phenotype was converted to a flat phenotype and the cells spread better on plastic (Figs. $5 \mathrm{j}$ and 5l).

These findings demonstrate that activation of the ras/MEK/ERK pathway is involved in the transition of the squamous to the more aggressive spindle phenotype. Effect of PD98059 on the Phosphorylation Status of ERK1/2
in PDVC57, PDVras, and A5 Cell Lines

To further strengthen the link between activation of the ras/MEK/ERK pathway and the abovementioned oncogenic properties, we studied the effect of PD98059 on ERK1/2 phosphorylation in the PDVC57, PDVras, and A5 cell lines. 
A
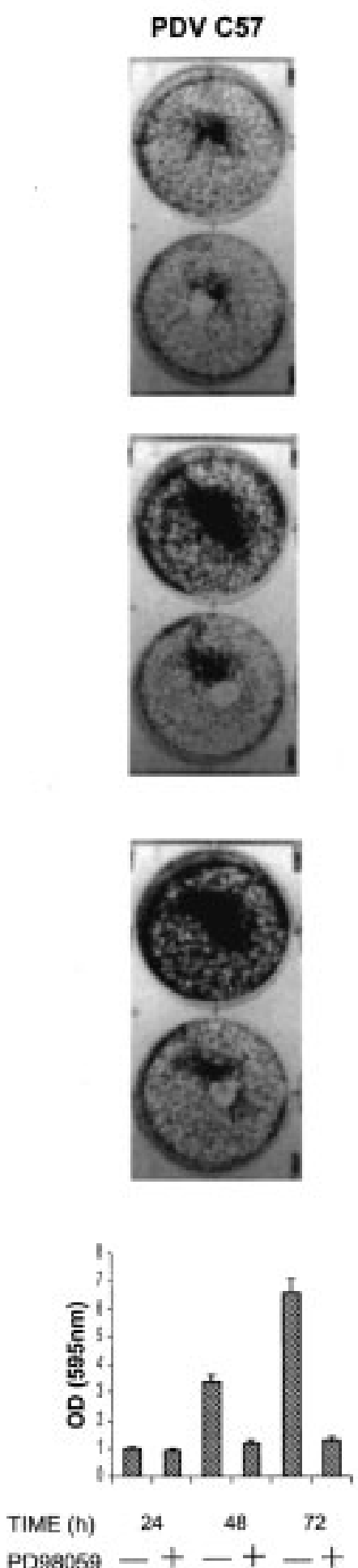

B
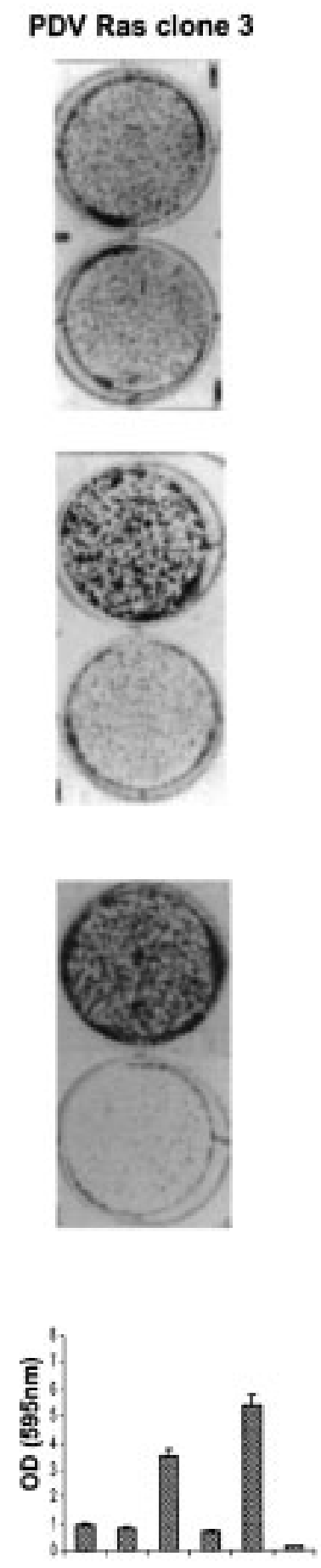

C

A5

Time (hrs) Pogsos:

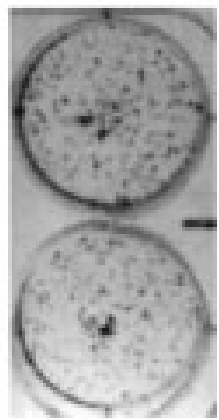

24

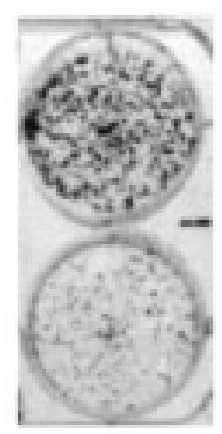

48

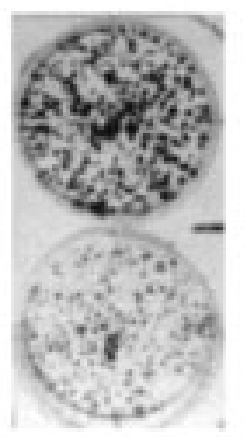

72
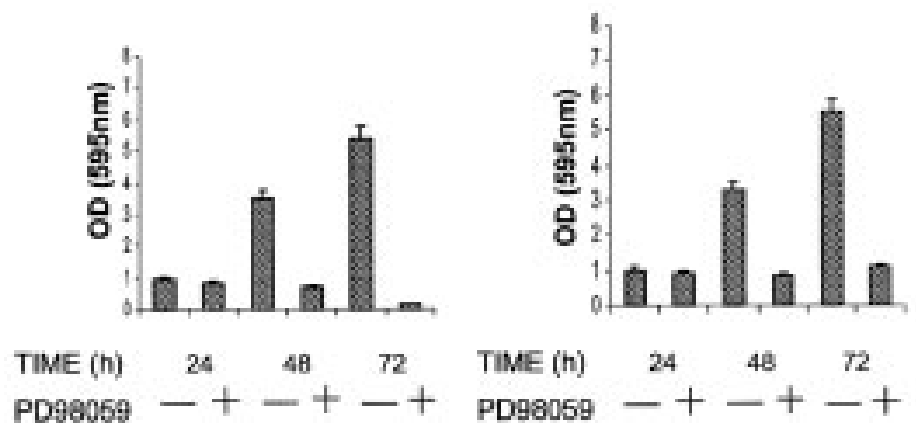

TIME (h)

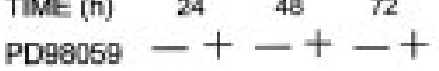

Fig. 3. The effect of PD98059 on colony formation and proliferation of PDVC57 (A), PDVras clone 3 (B), and A5 cells (C). The cells were plated on 6-well dishes and left to grow for $48 \mathrm{hr}$. The initial cell number was different for each cell line (PDVC57 $5 \times$ $10^{4}$, PDV ras $4 \times 10^{4}$, A5 $2 \times 10^{4}$ ); each cell line presents different proliferation rate. Then $50 \mu \mathrm{M}$ of PD98059 was added or the cells were left untreated. After 24 and $48 \mathrm{hr}$, fresh inhibitor was added to the medium. The colonies were stained 24, 48, or 72 hr after the addition of PD98059. At the bottom of each panel with photographs from the six well plates, a representation of proliferation rate is depicted as a growth chart corresponding to each cell line. The values on the $y$ axis represent the ratio of OD (595 nm) at each time point/OD $(595 \mathrm{~nm})$ of untreated cells at time point $24 \mathrm{hr}$. The experiment shown represents data pooled from three independent determinations. 


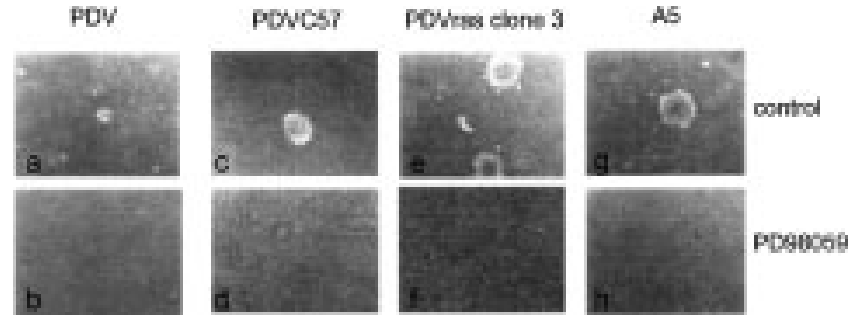

Fig. 4. Anchorage-independent growth. Anchorageindependent growth was monitored by growth in soft agar. PDV, PDVras clone 3, PDVC57, and A5 cells were plated on 6well dishes in $0.3 \%$ agar on the top of $0.6 \%$ agar and allowed to grow for 3 weeks. Every 4 days $300 \mu \mathrm{l}$ of medium with or without $50 \mu \mathrm{M}$ PD98059 was added to ensure that sufficient amount of fresh inhibitor was present. The colonies were photographed at $20 \times$ magnification.

The phosphorylation status of ERK1/2 was examined using a phosphospecific antibody against the dually phosphorylated ERK1/2. ERK-1 and ERK-2 phosphorylation in PDVC57 was found to increase over time, reaching a 4 -fold increase at $48 \mathrm{hr}$ (Fig. 6a). In these cells, ERK 1/2 phosphorylation was found to be sensitive to PD98059 inhibition, resulting in reduction of both ERK-1 and ERK-2 phosphorylated isoforms. To verify equal protein loading of all samples, the filter was probed with an antibody specific for total ERK-2 (Fig. 6a, top panel). In a similar manner, in cycling PDVras clone 3 cells, the levels of ERK $1 / 2$ phosphorylation, particularly ERK-1, increased over time (Fig. 6b). When treated with PD98059, as observed in the PDVC57 cells, both ERK isoforms were significantly reduced when compared to the untreated

Table 1. Soft agar cloning efficiency of squamous and spindle cells

\begin{tabular}{lcc}
\hline Cell Line & Inhibitor & Colony Numbers \\
\hline PDV & Control & 11 \\
PDV & DMSO & 10 \\
PDV & PD98059 & 0.0 \\
PDV Ras 3 & Control & 27 \\
PDV Ras 3 & DMSO & 23 \\
PDV Ras 3 & PD98059 & 0.0 \\
PDVC57 & Control & 19 \\
PDVC57 & DMSO & 16 \\
PDVC57 & PD98059 & 0.0 \\
A5 & Control & 36 \\
A5 & DMSO & 29 \\
A5 & PD98059 & 0.0
\end{tabular}

Colonies were scored after 3 weeks; each value represents actual numbers averaged from duplicate determinations (28).

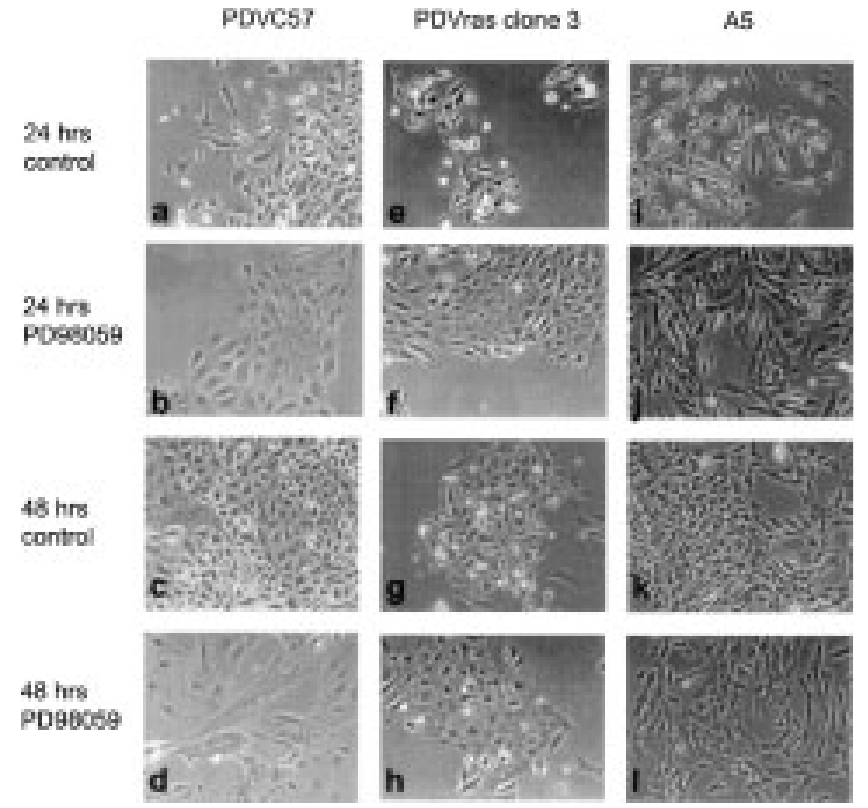

Fig. 5. PD98059 interferes with morphology in PDV, PDVras clone 3 and reverts the spindle phenotype of A5 cells. The cells were plated on 6-well dishes and left to grow for $48 \mathrm{hr}$. Then $50 \mu \mathrm{M}$ of PD98059 was added or the cells were left untreated. After $24 \mathrm{hr}$, fresh inhibitor was added to the medium. The photographs were taken at 24 and $48 \mathrm{hr}$ postaddition of PD98059 (20× magnification).

control time points. In contrast to this in cycling A5, both ERK-1 and ERK-2 isoforms were constitutively phosphorylated (Fig. 6c).

This finding suggests that the transition from squamous to the spindle morphology is associated with alteration of the subcellular environment that leads to an increase in the inhibition threshold of the activated MAPK pathway.

\section{ERK1/2 Signaling Affects the Expression and the Posttranslational Modifications of the \\ Fra-1 AP-1 Component}

We recently demonstrated that Fos-related antigen-1 (Fra-1) phosphorylation is elevated in A5 spindle cells (14). It has been shown that Fra-1 is phosphorylated in vivo (29) and can be phosphorylated by purified MAP kinase in vitro (30). In NIH3T3 fibroblasts transformed by ras, Fra- 1 is also phosphorylated (29). In an attempt to recognize downstream targets of ERK $1 / 2$ in our system, we examined the phosphorylation status of Fra-1 after treatment with PD98059 in the PDVC57 cell line. We observed that the slower-migrating isoforms were significantly reduced after treatment with the inhibitor for 6, 24, and $48 \mathrm{hr}$ (Fig. 6d).

This finding is in accordance with that of Treinies et al. (31), who showed that the slowermigrating isoforms of phosphorylated Fra-l are reduced when ras-transformed NIH3T3 cells are treated chronically with PD98059, and suggests that Fra-l is a downstream effector of the activated 
a

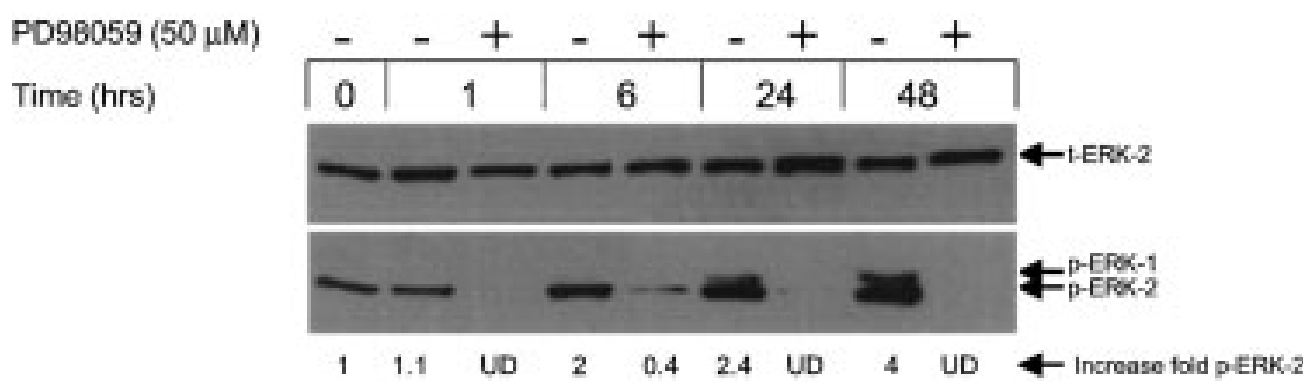

b

PD98059 (50 $\mu \mathrm{M})$

Time (hrs)

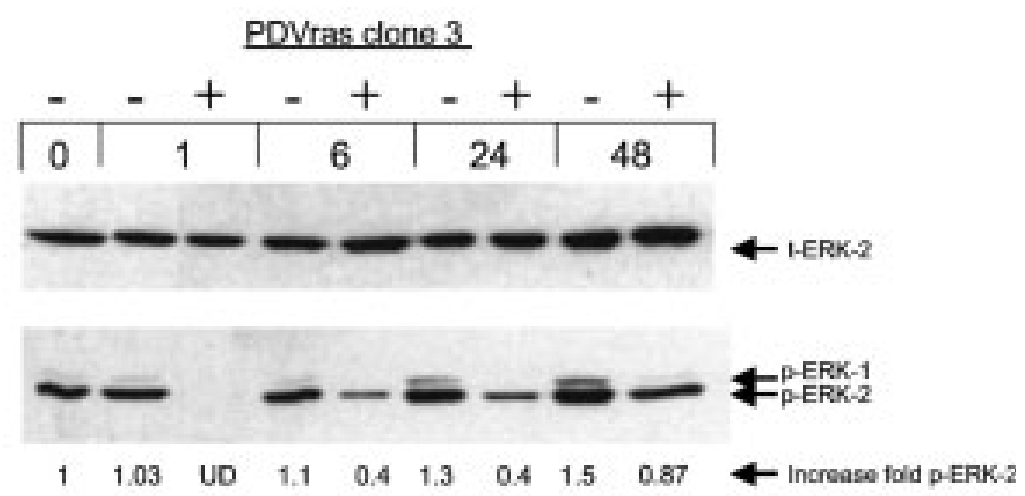

C

PDg8059 (50 $\mu \mathrm{M})$

Time (hrs)

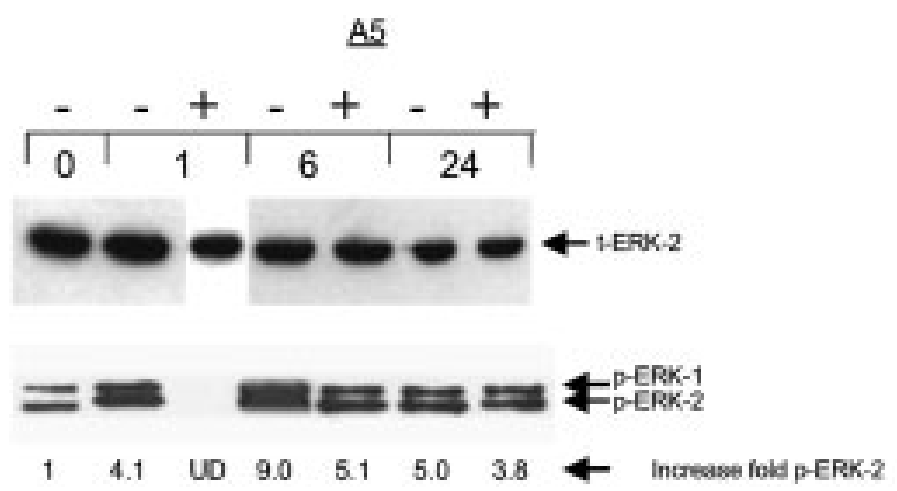

d

PDg8059 (50 $\mu \mathrm{M})$

Time (hrs)

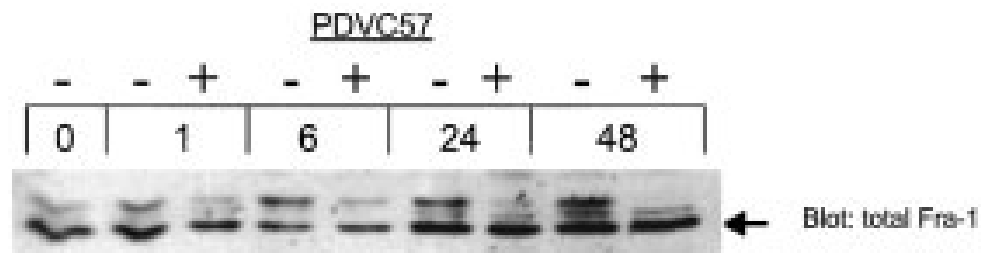

Fig. 6. The effect of PD98059 on the phosphorylation of ERK1/2 in squamous and spindle carcinoma cell derived from mouse skin tumors. (a) ERK1/2 phosphorylation in PDVC57 cells grown in DMEM with $10 \%$ FBS and treated with $50 \mu$ M of PD98059 for 1, 6, 24, and $48 \mathrm{hr}$. After $24 \mathrm{hr}$, fresh inhibitor was added to the medium. ERK1/2 phosphorylation was analyzed by Western immunoblotting with an anti-ERK1/2 phosphospecific antibody (bottom panel). To ensure equal protein loading, the nitrocellulose was probed with ERK-2-specific antibody (top panel). (b) ERK 1/2 phosphorylation in PDVras clone cells grown in DMEM with $10 \%$ FBS and treated with $50 \mu \mathrm{M}$ of PD98059 for 1, 6, 24, and $48 \mathrm{hr}$. After $24 \mathrm{hr}$, fresh inhibitor was added to the medium. ERK1/2 phosphorylation was analyzed by Western immunoblotting with an anti-ERK1/2 phosphospecific antibody (bottom panel). To ensure equal protein loading, the nitrocellulose was probed with ERK-2-specific antibody (top panel). (c) ERK1/2 phosphorylation in A5 cells grown in DMEM with 10\% FBS and treated with $50 \mu \mathrm{M}$ of PD98059 for 1, 6, and 24 hr. ERK1/2 phosphorylation was analyzed by Western immunoblotting with an anti-ERK 1/2 phosphospecific antibody (bottom panel). To ensure equal protein loading, the nitrocellulose was probed with ERK-2 specific antibody (top panel). (d) Expression of Fra-1 protein. Fra-1 expression was analyzed in PDVC57 cells grown in DMEM with 10\% FBS and treated with $50 \mu \mathrm{M}$ of PD98059 for 1, 6, 24, and 48 hr. After 24 hr, fresh inhibitor was added to the medium. Fra-1 protein was detected by Western blotting using an antibody specific for Fra-1. The arrow indicates the faster-migrating, nonphosphorylated form that accumulates after treatment with PD98059. 
ras/MEK/ERK pathway in the mouse skin carcinogenesis system.

\section{ERK1/2 Activity is Maintained in A5 Spindle Cells During Growth in Serum-Free Medium}

Transformation of fibroblasts by ras or murine sarcoma virus leads to the secretion of growth factors when cells are in serum-free medium. These growth factors support cell proliferation through the existence of an autocrine loop (32). The A5 carcinoma cells contain high levels of activated Ha-ras and display a spindle, refractile morphology reminiscent to that of ras-transformed fibroblasts (Fig. 5i). The spindle morphology of A5 cells can be reversed by treatment with PD98059 (Fig. 5j).

To investigate whether activation of the ras/ MEK/ERK pathway is independent from serum growth factors, we examined the morphology and ERK 1/2 phosphorylation status of A5 cells in serum-free medium. A5 grown in the absence of serum for $48 \mathrm{hr}$ were found to retain the spindle morphology (Fig. 7a). Treatment of these cells with PD98059 reverted the spindle phenotype to a flat, similar to that of a normal immortalized fibroblast (Fig. 7a). Next, examining ERK 1/2 phosphorylation we found it to be elevated compared to untreated cells (Fig. 7b, control compared to $24 \mathrm{hr}[-]$ and $48 \mathrm{hr}[-])$. Incubation of serum-starved A5 cells with PD98059 for $24 \mathrm{hr}$ was not sufficient to completely reduce ERK1/2 phosphorylation and a $48-\mathrm{hr}$ treatment was required to abolish this effect (Fig. 7b control compared to $24 \mathrm{hr}[+]$ and $48 \mathrm{hr}[+])$.

Both results suggest that the spindle morphology of A5 cells is controlled by ERK1/2 signaling, which is independent of serum growth factors.

The Invasive Properties of A5 Cells Depend on ERK1/2 Signaling

Invasive tumors secrete proteases-enabling tumor cells to invade through the extracellular matrix and thus to migrate to distant locations (33). Some of these proteases are regulated by growth factor signaling pathways.

In the mouse system, the metalloprotease MMP9/gelatinase B correlates with tumor progression (23). MMP-9 protein is overexpressed and its activity is augmented in the spindle A5 cell line (23). The expression of MMP-9 is regulated by ERK1/2 signaling and AP-1 elements in its promoter region, demonstrating directly that it is a ras-target gene (34). To establish a link between ERK1/2 signaling and the invasive properties of the A5 cells, we examined A5 conditioned medium for MMP-9 gelatinolytic activity. This experiment was performed both in the absence and presence of PD98059 to test inhibition of MMP-9 activity when ras signaling is blocked. MMP-9 enzymatic activity was assessed using zymogram analysis (Fig. 7c). MMP-9 proteolytic activity was found to be reduced upon treatment of serum-starved A5 cells with PD98059 (Fig. 7c track 2), a

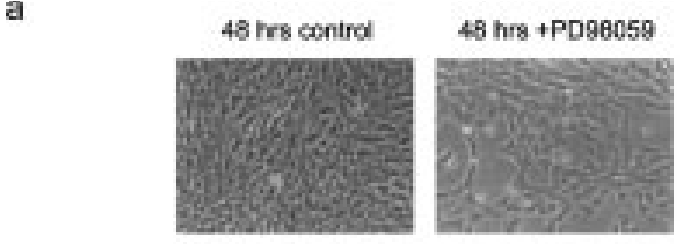

b

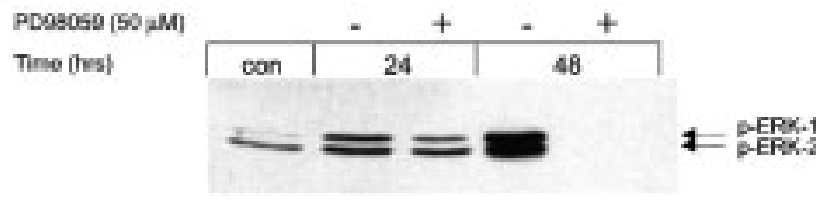

c

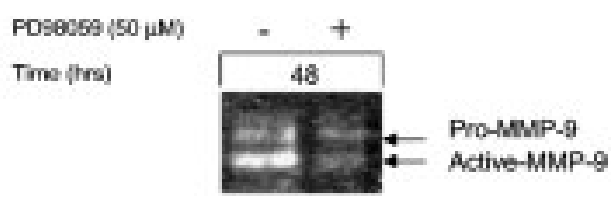

Fig. 7. Morphologic changes and suppression of ERK1/2 phosphorylation in A5 cells by PD98059 during growth in serum-free medium. (a) A5 cells were plated on 6-well dishes in DMEM with 10\% FBS and grown for $24 \mathrm{hr}$. After $24 \mathrm{hr}$, the medium was changed to serum-free DMEM and $50 \mu \mathrm{M}$ of PD98059 was added or the cells were left untreated. The photographs were taken $48 \mathrm{hr}$ after the addition of PD98059. (b) The effect of PD98059 on ERK1/2 phosphorylation in A5 cells growing in serum-free medium. ERK1/2 phosphorylation in A5 cells in serum-free DMEM at times $0 \mathrm{hr}$ (first track) and after 24 and $48 \mathrm{hr}$ in serum-free DMEM control or treated with $50 \mu \mathrm{M}$ of PD98059. After $24 \mathrm{hr}$, fresh inhibitor was added to the medium. ERK1/2 phosphorylation was analyzed by Western immunoblotting with an anti-ERK 1/2 phosphospecific antibody. (c) MMP-9 activity of A5 cells growing in serum-free medium in the absence and presence of $50 \mu \mathrm{M}$ of PD98059. A5 cells were plated on 6-well dishes and left to grow for $24 \mathrm{hr}$. The medium was then changed to serum-free DMEM and $50 \mu \mathrm{M}$ of PD98059 was added or the cells were left untreated. Conditioned medium was collected and MMP-9 activity was assessed according to the protocol described in Materials and Methods. Upper arrow indicates pro-MMP-9 and lower arrow active MMP-9.

suggesting that the potentiation of gelatinolytic activity of this protease is dependent on this pathway.

\section{Discussion}

ERK1/2 Signaling is Required for Squamous Oncogenicity

Chemically induced multistage carcinogenesis in mice is associated with alterations in protooncogenes and tumor-suppressor genes (2). These genetic changes result in the appearance of papilloma, squamous, and at later stages progress to invasive, spindle carcinomas (Fig. 1). The Ha-ras proto-oncogene plays an important role from the initial stages of this stepwise progression, because it is mutated to an activated form by the initiating carcinogen DMBA $(22,35)$. The mutant Ha-ras allele during the following steps is further duplicated or amplified and seems to be involved in the squamous to 
spindle transition (2). However, the exact nature of Ha-ras involvement during this process is still unclear.

Recently, in attempt to detect intracellular targets of the ras signaling pathway (36), we demonstrated that activation of the Jun $\mathrm{N}$-terminal kinase (JNK) cascade and elevated phosphorylation of AP-1 components correlated with malignant progression in the mouse skin carcinogenesis model (14). Notably, JNK activity and phosphorylation of AP-1 constituents are dramatically increased in the spindle tumor cells, which correspond to the latest and more aggressive phenotypic stage of the mouse skin carcinogenetic process.

These findings and the fact that the mutant: normal Ha-ras gene ratio is increased during progression from the benign (papilloma) to the malignant (squamous-spindle) stage of the mouse skin model prompted us to examine the activation status of its downstream effector ERK1/2. Phosphorylated ERK $1 / 2$ showed a progressive increase from the papilloma to the squamous and spindle cell lines implying that ERK1/2 signaling is involved in malignant progression of mouse skin tumors. In accordance are the results of Sivaraman et al. (37), who demonstrated that primary human breast carcinomas exhibited a 5- to 10-fold increase ERK 1/2 activity over benign conditions, such as fibroadenomas and fibrocystic disease. Interestingly, this gradual elevation of ERK1/2 activation was also observed within the squamous PDV:PDVC57 cell pair. The squamous PDV and PDVC57 cell lines are derived from tumors originated from the same progenitor cell but differ, as we mentioned, in the normal:mutated Ha-ras ratio (5). Given that PDVC57 has more malignant characteristics than PDV, our finding implies that ERK $1 / 2$ signaling may play a role in the degree of aggressiveness during the squamous stage of mouse skin carcinogenesis. To prove that this increase in ERK 1/2 signaling was related to the qualitative changes of the endogenous Ha-ras, we attempted to reproduce the putative effects of ras by introducing in the PDV cells an activated Ha-ras allele (16). Indeed, the phosphorylation pattern of ERK $1 / 2$ in the PDVras clones was comparable to that of PDVC57, confirming our initial hypothesis. Although several groups have shown that ras is required for the activation of the MAP kinase pathway in several cell types (38-40), this is the first study to demonstrate a gradual increase of the ras/MEK/ERK pathway during the various stages of mouse skin carcinogenesis.

Next, to examine if the ras/MEK/ERK pathway is required for the manifestation of tumorigenic properties of the PDVC57 cells and PDVras transfectants, we used a pharmacologic approach. In particular, their ability to form colonies and anchorageindependent growth was investigated in the presence of the MEK-1 inhibitor, PD98059. Both characteristics were inhibited after treatment with
PD98059, implying that proliferation and tumorigenicity of squamous carcinomas of mouse skin are ras/MEK/ERK1/2 pathway-dependent. A similar approach was employed recently by Sebolt-Leopold et al. (41), who inhibited tumor growth by as much as $80 \%$ in mice inoculated with human or mouse colon carcinoma cells using the MEK-1 inhibitor PD 184352. Administration of PD 184352 resulted in the reduction of ERK1/2 phosphorylation, tumor volume, and invasion potential (41).

\section{ERK1/2 Signaling Contributes to the Expression} of the Spindle Phenotype

One of the major changes found at the later stages of tumor progression is the conversion from an epithelial to mesenchymal phenotype. This is termed epithelial-mesenchymal transition (EMT) (42). Ras and TGF- $\alpha$ signaling pathways are important for the induction of EMT in vitro and in vivo (43-45). The transition to spindle phenotype is a recessive event during mouse multistage carcinogenesis (2). EMT induced in vitro by growth factors and certain oncogenes suggests that a common epithelial precursor of spindle cells is sensitive to conversion by oncogenic growth factor signaling (46-49).

From later stages of the mouse skin carcinogenesis model Burns et al. (19) isolated the B9:A5 cell pair. The B9 and A5 cells were derived from a common precursor and they contain the same Ha-ras and p53 tumor-suppressor mutations (19). B9 is a squamous cell carcinoma and A5, which was derived from B9, is an anaplastic and invasive cell line with spindle phenotype (19). This pair offers the advantage of the common origin between squamous and spindle tumors shown by genetic analyses and protein localization studies in intact cells by immunofluorescence (50). Transforming ras introduced into human mammary epithelial and MDCK cells has been reported to be involved in the induction of EMT, resulting in the appearance of a fibroblastic phenotype (51) as a consequence of elevated Ras activity and tyrosine phosphorylation $(52,53)$. It has been shown that signaling by transforming ras down-regulates Rac activity through the Raf/MEK/ERK pathway. Raf/MEK/ERK signaling down-regulates Tiam-1, an exchange factor for Rac, leading to decreased Rac activity and increased Rho activity participating in EMT (54).

In our study, ERK1/2 signaling in B9 (as demonstrated by ERK1/2 phosphorylation status) is reduced when compared to the spindle $\mathrm{A} 5$ and CarB cells. This could be ascribed to increased mutant Ha-ras present in A5 and CarB cells (14). Proliferation of A5 is suppressed by PD98059. Treatment with inhibitor resulted in a relative decrease of levels of ERK 1/2 phosphorylation between 6 and $24 \mathrm{hr}$. Prolonged treatment of A5 cells with PD98059 up to $48 \mathrm{hr}$ appears to be necessary to abrogate ERK1/2 phosphorylation, suggesting that in A5 cells both ERK-1 and ERK-2 isoforms are phosphorylated to 
high levels and remain refractory to pharmacologic inhibition by PD98059 when compared to squamous carcinoma cells.

ras-Transformed fibroblasts and epithelial cells secrete growth factors in an autocrine fashion. These secreted growth factors enable cells to grow in the absence of serum (55-57). Transforming growth factors such as TGF- $\alpha$ secreted in the conditioned medium of these cells allow them to grow in the absence of serum (58). It is known that growth factor activation of ras and regulation of AP-1 activity are required for morphologic transformation, proliferation, and invasion (59). A5 cells have a fibroblastic phenotype and contain high levels of mutant Ha-ras, resulting in elevated ERK1/2 signaling. To test whether autocrine signals present in $\mathrm{A} 5$ cells activate ras-ERK $1 / 2$ signaling and are required for spindle morphology, serum-starved A5 were examined in terms of morphology and ERK1/2 phosphorylation. Serum starvation of A5 cells did not have any effect on the spindle phenotype. ERK 1/2 phosphorylation also remained persistent in serum-free A5 growing cells. To test if ERK $1 / 2$ activation is dependent on ras signaling, A5 cells were treated with PD98059. Serum-free A5 treated with PD98059 displayed a flat phenotype and reduced ERK1/2 phosphorylation when exposed to 48 -hr treatment.

Sustained versus transient activation of ERK1/2 signaling results in differential changes in proliferation and morphology of some cell types. Cook and McCormick (60) reported that sustained activation of ERK-1 by LPA in Rat-1 cells is a determinant of cell proliferation. By contrast, in PC12 cells, sustained ERK 1/2 activity by NGF induces cell differentiation. Incubation of PC 12 cells with EGF induces a transient activation of ERK $1 / 2$ and cell proliferation $(61,62)$. Therefore, different cell types exhibit different effects by the activation of Raf/MEK/ERK signaling. Our results show that sustained activation of ERK 1/2 in A5 cells could well be a determinant of morphologic changes in spindle cells.

The MEK-1 inhibitor, PD98059, reverts the spindle morphology not to an epithelial but to a flat phenotype, similar to that of normal immortalized fibroblasts such as Rat- 1 cells. The potency of PD98059 to induce this change both in the presence and absence of serum suggests that inhibition of ras signaling through inhibition of ERK $1 / 2$ activity is sufficient to elicit this effect. In the mouse system induction of the spindle phenotype is recessive (2). Suppression of ras-ERK $1 / 2$ signaling may be sufficient for partial reversion, compensating for the putative loss of a master gene deleted during progression toward the spindle phenotype that controls epithelial differentiation (R. Crombie, et al., unpublished study).

It is well known that alterations of Ha-ras are one of the main features of tumor progression in the mouse skin (21). As demonstrated in this study, these in vivo alterations of Ha-ras lead most likely to elevated ERK1/2 signaling. Based on our results in the PDVC57 squamous cell carcinomas, it is plausible that suppression of ras signaling at early stages could be potentially beneficial in clinical applications for the inhibition of tumor growth. However at later stages, for example in spindle tumors, where mutated Ha-ras is also amplified, it is likely that it would be more difficult to suppress growth of these cancers simply by interfering with one downstream signaling component controlled by this oncogene.

\section{Acknowledgments}

This work is supported by a Grant from the Greek Secretariat for Research and Technology (G.S.R.T.) (99ED 609/ PENED 99). We thank Alexandra Papathoma for the MMP assay, Vivi Pappasava for the transfections, and Dr Spiros Linardopoulos for comments.

\section{References}

1. Barbacid M. (1987) ras genes. Annu. Rev. Biochem. 56: 779-827.

2. Frame S, Crombie S, Liddell J, et al. (1998) Epithelial carcinogenesis in the mouse: correlating the genetics and the biology. Philos. Trans. R. Soc. Lond. B Biol. Sci. 353: 839-845.

3. Balmain A, Brown K. (1988) Oncogene activation in chemical carcinogenesis. Adv. Cancer Res. 5: 147-182.

4. Quintanilla M, Haddow S, Jonas D, Jaffe D, Bowden GT, Balmain A. (1991) Comparison of ras activation during epidermal carcinogenesis in vitro and in vivo. Carcinogenesis 12: 1875-1881.

5. Buchmann A, Ruggeri B, Klein-Szanto AJ, Balmain A. (1991) Progression of squamous carcinoma cells to spindle carcinomas of mouse skin is associated with an imbalance of $\mathrm{H}$-ras alleles on chromosome 7. Cancer Res. 51: 4097-4101.

6. Troppmair J, Bruder JT, Munoz H, et al. (1994) Mitogenactivated protein kinase/extracellular signal-regulated protein kinase activation by oncogenes, serum, and 12-Otetradecanoylphorbol-13-acetate requires $\mathrm{Raf}$ and is necessary for transformation. J. Biol. Chem. 269: 7030-7035.

7. Khosravi-Far R, Solski PA, Clark GJ, Kinc MS, Der CJ. (1995) Activation of Racl, RhoA, and mitogen-activated protein kinases is required for Ras transformation. Mol. Cell Biol. 15: 6443-6453.

8. Khosravi-Far R, White MA, Westwick JK, et al. (1996) Oncogenic Ras activation of Raf/mitogen-activated protein kinaseindependent pathways is sufficient to cause tumorigenic transformation. Mol. Cell Biol. 16: 3923-3933.

9. Rodriguez-Viciana $\mathrm{P}$, Warne $\mathrm{PH}$, Dhand R, et al. (1994) Phosphatidylinositol-3-OH kinase as a direct target of Ras. Nature 370: 527-532.

10. Diaz-Meco MT, Lozano J, Municio MM, et al. (1994) Evidence for the in vitro and in vivo interaction of Ras with protein kinase C zeta. J. Biol. Chem. 269: 31706-31710.

11. Russell M, Lange-Carter CA, Johnson GL. (1995) Direct interaction between Ras and the kinase domain of mitogenactivated protein kinase kinase kinase (MEKK 1). J. Biol. Chem. 270: 11757-11760.

12. Boguski MS, McCormick F. (1993) Proteins regulating Ras and its relatives. Nature 366: 643-654.

13. White MA, Vale T, Camonis JH, Schaefer E, Wigler MH. (1996) A role for the Ral guanine nucleotide dissociation stimulator in mediating Ras-induced transformation. J. Biol. Chem. 271: 16439-16442.

14. Zoumpourlis V, Papassava P, Linardopoulos S, Gillespie D, Balmain A, Pintzas A. (2000) High levels of phosphorylated c-Jun, Fra-1, Fra-2 and ATF-2 proteins correlate with malignant phenotypes in the multistage mouse skin carcinogenesis model. Oncogene 19: 4011-4021. 
15. Fusenig NE, Drazlieva-Petrusevska RT, Breitkreutz D. (1985) Phenotypic and cytogenetic characteristics of different stages during spontaneous transformation of mouse keratinocytes in vitro. Carcinog. Compr. Surv. 9: 293-326.

16. Spandidos DA, Wilkie NM. (1984) Malignant transformation of early passage rodent cells by a single mutated human oncogene. Nature 310: 469-475.

17. Dudley DT, Pang L, Decker SJ, Bridges AJ, Saltiel AR. (1995) A synthetic inhibitor of the mitogen-activated protein kinase cascade. Proc. Natl. Acad. Sci. U.S.A. 92: 7686-7689.

18. Diaz-Guerra M, Haddow S, Baulur C, et al. (1992) Expression of simple epithelial keratins in mouse epidermal keratinocytes harbouring Harvey ras gene alterations. Cancer Res. 52: 680-687.

19. Burns PA, Kemp CJ, Gannon JV, Lane DP, Bremner R, Balmain A. (1991) Loss of heterozygosity and mutational alterations of the p53 gene in skin tumors of interspecific hybrid mice. Oncogene 6: 2363-2369.

20. Haddow S, Fowlis DJ, Parkinson K, Akhurst RJ, Balmain A. (1991) Loss of growth control by TGF- $\beta$ occurs at a late stage of mouse skin carcinogenesis and is dependent of ras gene activation. Oncogene 6: 1465-1470.

21. Bremner R, Balmain A. (1990) Genetic changes in skin tumor progression: correlation between presence of a mutant ras gene and loss of heterozygosity on mouse chromosome 7. Cell 61: 407-417.

22. Quintanilla M, Brown K, Ramsden M, Balmain A. (1986) Carcinogen-specific mutation and amplification of Ha-ras during mouse skin carcinogenesis. Nature 322: 78-80.

23. Papathoma A, Zoumpourlis V, Balmain A, Pintzas A. (2001) The role of matrix metalloproeinase-9 in progression of mouse skin carcinogenesis. Mol. Carcinog. 31: 74-82.

24. Stacey DW, Tsai MH, Yu CL, Smith JK. (1988) Critical role of cellular ras proteins in proliferative signal transduction. Cold Spring Harb. Symp. Quant. Biol. 53: 871-881.

25. Waters SB, Holt KH, Ross SE, et al. (1995) Desensitization of Ras activation by a feedback disassociation of the SOS-Grb2 complex. J. Biol. Chem. 270: 20883-20886.

26. Pang L, Sawada T, Decker SJ, Saltiel AR. (1995) Inhibition of MAP kinase kinase blocks the differentiation of PC-12 cells induced by nerve growth factor. J. Biol. Chem. 270: 13585-13588.

27. Shin SI, Freedman VH, Risser R, Pollack R. (1975) Tumorigenicity of virus-transformed cells in nude mice is correlated specifically with anchorage independent growth in vitro. Proc. Natl. Acad. Sci. U.S.A. 72: 4435-4439.

28. Shirasawa S, Furuse M, Yokoyama N, Sasazuki T. (1993) Altered growth of human colon cancer cell lines disrupted at activated Ki-ras. Science 260: 85-88.

29. Lallemand D, Spyrou G, Yaniv M, Pfarr CM. (1997) Variations in Jun and Fos protein expression and AP-1 activity in cycling, resting and stimulated fibroblasts. Oncogene 14: 819-830.

30. Gruda MC, Kovary K, Metz R, Bravo R. (1994) Regulation of Fra- 1 and Fra-2 phosphorylation differs during the cell cycle of fibroblasts and phosphorylation in vitro by MAP kinase affects DNA binding activity. Oncogene 9: 2537-2547.

31. Treinies I, Paterson HF, Hooper S, Wilson R, Marshall CJ.(1999) Activated MEK stimulates expression of AP-1 components independently of phosphatidylinositol 3-kinase (PI3-kinase) but requires a PI3-kinase signal to stimulate DNA synthesis. Mol. Cell Biol. 19: 321-329.

32. Sporn MB, Todaro GJ. (1980) Autocrine secretion and malignant transformation of cells. N. Engl. J. Med. 303: 878-880.

33. MacDougall JR, Matrisian LM. (1995) Contributions of tumor and stromal matrix metalloproteinases to tumor progression, invasion and metastasis. Cancer Metastasis Rev. 14: 351-362.

34. Gum R, Wang H, Lengyel E, Juarez J, Boyd D. (1997) Regulation of $92 \mathrm{kDa}$ type IV collagenase expression by the jun aminoterminal kinase- and the extracellular signal-regulated kinase-dependent signaling cascades. Oncogene 14: 1481-1493.

35. Brown K, Buchmann A, Balmain A. (1989) Carcinogeninduced mutations in the mouse c-Ha-ras gene provide evidence of multiple pathways for tumor progression. Proc. Natl. Acad. Sci. U.S.A. 87: 538-542.
36. Karin M. (1995) The regulation of AP-1 activity by mitogenactivated protein kinases. J. Biol. Chem. 270: 16483-16486.

37. Sivaraman VS, Wang H, Nuovo GJ, Malbon CC. (1997) Hyperexpression of mitogen-activated protein kinase in human breast cancer. J. Clin. Invest. 99: 1478-1483.

38. Wood KW, Sarnecki C, Roberts TM, Blenis J. (1992) ras mediates nerve growth factor receptor modulation of three signaltransducing protein kinases: MAP kinase, Raf-1, and RSK. Cell 68: 1041-1050.

39. Leevers SJ, Marshall CJ. (1992) Activation of extracellular signal-regulated kinase, ERK2, by p2 lras oncoprotein. EMBO J. 11: 569-574.

40. Qui MS, Green SH. (1992) PC12 cell neuronal differentiation is associated with prolonged p2 lras activity and consequent prolonged ERK activity. Neuron 9: 705-717.

41. Sebolt-Leopold JS, Dudley DT, Herrera R, et al. (1999) Blockade of the MAP kinase pathway suppresses growth of colon tumors in vivo. Nat. Med. 5: 810-816.

42. Thiery JP, Chopin D. (1999) Epithelial cell plasticity in development and tumor progression. Cancer Metastasis Rev. 18: 31-42.

43. Oft M, Peli J, Rudaz C, Schwarz H, Beug H, Reichmann E. (1996) TGF-betal and Ha-ras collaborate in modulating the phenotypic plasticity and invasiveness of epithelial tumor cells. Genes Dev. 10: 2462-2477.

44. Oft M, Heider KH, Beug H. (1998) TGFbeta signaling is necessary for carcinoma cell invasiveness and metastasis. Curr. Biol. 19: 1243-1252.

45. Lehmann K, Janda E, Pierreux CE, et al. (2000) Raf induces TGFbeta production while blocking its apoptotic but not invasive responses: a mechanism leading to increased malignancy in epithelial cells. Genes Dev. 14: 2610-2622.

46. Caulin C, Scholl FG, Frontelo P, Gamallo C, Quintanilla M. (1995) Chronic exposure of cultured transformed mouse epidermal cells to transforming growth factor-beta 1 induces an epithelial-mesenchymal transdifferentiation and a spindle tumoral phenotype. Cell Growth Differ. 6: 1027-1035.

47. Jouanneau J, Gavrilovic J, Caruelle D, et al. (1991) Secreted or nonsecreted forms of acidic fibroblast growth factor produced by transfected epithelial cells influence cell morphology, motility, and invasive potential. Proc. Natl. Acad. Sci. U.S.A. 88: 2893-2897.

48. Redmond SM, Reichmann E, Muller RG, Friis RR, Groner B, Hynes NE. (1988) The transformation of primary and established mouse mammary epithelial cells by p21-ras is concentration dependent. Oncogene 2: 259-265.

49. Reichmann E, Schwarz H, Deiner EM, et al. (1992) Activation of an inducible c-FosER fusion protein causes loss of epithelial polarity and triggers epithelial-fibroblastoid cell conversion. Cell 7: 1103-1116.

50. Stoler AB, Stenback F, Balmain A. (1993) The conversion of mouse skin squamous cell carcinomas to spindle cell carcinomas is a recessive event. J. Cell Biol. 122: 1103-1117.

51. Zhong C, Kinch MS, Burridge K. (1997) Rho-stimulated contractility contributes to the fibroblastic phenotype of Rastransformed epithelial cells. Mol. Biol. Cell 8: 2329-2344.

52. Kinch MS, Clark GJ, Der CJ, Burridge K. (1995) Tyrosine phosphorylation regulates the adhesions of ras-transformed breast epithelia. J. Cell Biol. 130: 461-471.

53. Behrens J, Vakaet L, Friis R, et al. (1993) Loss of epithelial differentiation and gain of invasiveness correlates with tyrosine phosphorylation of the E-cadherin/beta-catenin complex in cells transformed with a temperature-sensitive v-SRC gene. J. Cell Biol. 120: 757-766.

54. Zondag GC, Evers EE, ten Klooster JP, et al. (2000) Oncogenic Ras downregulates Rac activity, which leads to increased Rho activity and epithelial-mesenchymal transition. J. Cell Biol. 149: 775-782.

55. de Larco JE, Todaro GJ. (1978) Growth factors from murine sarcoma virus-transformed cells. Proc. Natl. Acad. Sci. U.S.A. 75: 4001-4005.

56. Scher CD, Pledger WJ, Martin P, Antoniades H, Stiles CD. (1978) Transforming viruses directly reduce the cellular 
growth requirement for a platelet derived growth factor. J. Cell Physiol. 97: 371-380.

57. Ozanne B, Fulton RJ, Kaplan PL. (1980) Kirsten murine sarcoma virus transformed cell lines and a spontaneously transformed rat cell-line produce transforming factors. J. Cell Physiol. 105: 163-180.

58. Gangarosa LM, Sizemore N, Graves-Deal R, Oldham SM, Der CJ, Coffey RJ. (1977) A raf-independent epidermal growth factor receptor autocrine loop is necessary for Ras transformation of rat intestinal epithelial cells. J. Biol. Chem. 272: 18926-18931.

59. Ozanne BW, McGarry L, Spence HJ, et al. (2000) Transcriptional regulation of cell invasion: AP-1 regulation of a multigenic invasion programme. Eur. J. Cancer 36: 1640-1648.
60. Cook SJ, McCormick F. (1996) Kinetic and biochemical correlation between sustained p44ERK1 (44 kDa extracellular signal-regulated kinase 1) activation and lysophosphatidic acid-stimulated DNA synthesis in Rat-1 cells. Biochem. J. 320: 237-245.

61. Traverse S, Seedorf K, Paterson H, Marshall CJ, Cohen P, Ullrich A. (1994) EGF triggers neuronal differentiation of PC12 cells that overexpress the EGF receptor. Curr. Biol. 4: 694-701.

62. Traverse S, Gomez N, Paterson H, Marshall C, Cohen P. (1992) Sustained activation of the mitogen-activated protein (MAP) kinase cascade may be required for differentiation of PC12 cells. Comparison of the effects of nerve growth factor and epidermal growth factor. Biochem. J. 288: 351-355. 